J. Amer. Soc. Hort. ScI. 115(1):29-33. 1990.

\title{
Establishment and Yield of Asparagus as Influenced by Planting and Irrigation Method
}

\author{
S.B. Sterrett ${ }^{1}$, B.B. Ross ${ }^{2}$, and C.P. Savage, Jr. $^{3}$ \\ Virginia Polytechnic Institute and State University, Blacksburg, VA 24061 \\ Additional index words. crowns, transplants, Asparagus officinalis, surface trickle, subsurface trickle, sprinkler
}

\begin{abstract}
New Jersey 'Syn 4' asparagus (Asparagus officinalis, L.) was grown on a sandy loam soil to compare plant survival and yield of asparagus grown from crowns and transplants under four irrigation treatments: sprinkler (SPR), surface trickle (ST), subsurface trickle (SST), and no irrigation (NI). While plant survival of crowns was not appreciably influenced by any irrigation treatment, survival of transplants was significantly increased by SST. Total and marketable yields from crowns and transplants were similar in the first harvest season (year 3). However, in years 4 and 5, the yield of crowns was higher than that of transplants. Subsurface trickle increased yield from transplants in years 4 and 5 and increased yield from crowns in year 5 . All irrigation methods significantly increased both spear production (spear/ha) and average spear weight. Subsurface trickle irrigation resulted in the largest increase over NI in total yield and spear production.
\end{abstract}

The yield of many hybrid asparagus cultivars is higher than that of older, open-pollinated cultivars (Benson and Takatori, 1980; Damicone and Manning, 1987; Mapplebeck and Tiesson, 1983; Price, et al., 1986). Although transplanting crowns is the primary method of establishing commercial asparagus plantings (Kirpes et al., 1985, Mapplebeck and Tiessen, 1983), the limited seed supply and grower interest in rapid establishment of these new cultivars has resulted in increased interest in using asparagus transplants. Use of greenhouse-grown transplants reduced risk of infection by fusarium wilt and crown rot $(F$. oxysporum and $F$. moniliforme), increased mechanization of planting, reduced planting time and labor, and more efficiently used expensive hybrid seed (Ombrello and Garrison, 1978; Fisher, 1982; Sanders, 1985).

Wilcox-Lee (1987) concluded that maximum growth occurs in young asparagus plants when soil water potential is close to field capacity, indicating that newly established plantings should benefit from irrigation to minimize moisture stress. Advantages of trickle irrigation over sprinkler irrigation are improved growth and early yield of perennial crops (Elfving, 1979), improved water efficiency over sprinklers (Elfving, 1982; Sammis, 1980), and maintenance of a fairly constant soil water content in the root zone (Bucks, et al., 1982). Furthermore, subsurface trickle irrigation requires less yearly labor than surface trickle, has a

Received for publication 5 Apr. 1989. We gratefully acknowledge the cooperation of Chapin Watermatics, Inc., for providing material and technical assistance. The cost of publishing this paper was defrayed in part by the payment of page charges. Under postal regulations, this paper therefore must be hereby marked advertisement solely to indicate this fact.

'Assistant Professor, Dept. of Horticulture, Virginia Polytechnic Institute and State Univ., Eastern Shore Agricultural Experiment Station, Painter, VA 23420. ${ }^{2}$ Associate Professor, Dept. of Agricultural Engineering Virginia Polytechnic Institute and State Univ., Blacksburg, VA 24061.

Agr. Res. Scientist A, Virginia Polytechnic Institute and State Univ., Eastern Shore Agricultural Experiment Station, Painter, VA 23420. longer life expectancy, increases water-use efficiency, and reduces soil compaction (Chase, 1985; Phene et al., 1987; Sammis, 1980). Yield enhancement has been reported for several row crops with subsurface trickle irrigation (Mitchell and Sparks, 1982; Phene et al., 1987).

A complete stand of vigorous plants is needed for long-term profitable production of asparagus (Mapplebeck and Tiessen, 1983). Ombrello and Garrison (1978) reported that, with sprinkler irrigation, plant survival was greater for transplants $(98 \%$ to $100 \%)$ than for direct seeding $(23 \%)$. The differences in plant establishment and yield of crowns and transplants have not been well-documented, particularly when supplemental irrigation is limited. Also, several researchers have reported positive correlations between vegetative growth measurements and yield, but plant population was not included in these models (Dufault and Greig, 1983; Ellison and Scheer, 1959; Moon, 1976). Our study evaluated the influence of irrigation and planting method (crowns or transplants) on plant establishment and subsequent yield and quality. The relationship between vegetative growth measurements, plant population, and yield was also evaluated.

\section{Materials and Methods}

One-year-old crowns and 9-week-old transplants of New Jersey 'Syn-4' asparagus were planted in Apr. 1984 (year 1) on a Bojac sandy loam (coarse-loamy, mixed thermic Typic Hapludult). Each plot consisted of two rows, $7.5 \mathrm{~m}$ in length and 1.5 $\mathrm{m}$ apart, with $0.3 \mathrm{~m}$ between plants within the row. Irrigation treatments included surface trickle (ST), subsurface trickle (SST), sprinkler (SPR), and a nonirrigated control (NI). A single trickle tube $(0.30 \mathrm{~mm})$ with $0.2-\mathrm{m}$ emitter intervals was installed in each record row of the trickle treatments. Subsurface trickle lines were installed in the planting furrow at a depth of $0.3 \mathrm{~m}$, and the furrow filled to $0.25 \mathrm{~m}$ before planting of crowns and transplants. The furrows were filled gradually during the first 
growing season. Hence, the tops of the established crowns were $\approx 0.21 \mathrm{~m}$ below the soil surface.

To avoid overlap of irrigation treatments, a common border row separated adjacent plots. Tensiometers were placed between plants in the second and third replicate of each irrigation/planting method combination, resulting in a total of 16 tensiometers. Irrigation was started on 7 May 1984, 7 May 1985, 20 May 1986, and 6 June 1987, respectively. Irrigation ceased on 30 Sept. of each year. Sprinkler irrigation was applied by microsprinklers on 0.6-m risers, wetting most of the fern in the record rows with minimum drift to adjacent border rows. Irrigation was applied to all replications of each treatment when soil moisture tension as measured by tensiometers within that treatment at the 0.3-m depth reached $20 \mathrm{kPa}$ (Pogue and Dooley, 1985). Irrigation was applied until tensiometers registered $0 \mathrm{kPa}$. After the first year, irrigation was needed on an average of every 5 to 7 days. Recommended cultural practices were followed regarding fertilizer and herbicide applications with insecticides applied as needed. During the first growing season, monthly average temperatures were within $1 \mathrm{C}$ of the 30-year monthly average temperatures for Painter, Va. (NOAA, 1984). However, precipitation was below the 30 -year average for June through October $(-30,-3,-91,-34$, and $-54 \mathrm{~mm}$, respectively) (NOAA, 1984).

Growth measurements were taken on 11 Nov. 1984, 9 Oct. 1985, 24 Nov. 1986, and 7 Oct. 1987. Plant population was recorded for each plot. Height of the tallest fern, diameter of the largest stem, and total number of stems per plant were recorded for 10 consecutive plants.

No spears were harvested during the first two growing seasons. Plots were harvested by cutting spears at the soil surface for 2 weeks in 1986 (year 3), 4 weeks in 1987 (year 4), and 7 weeks in 1988 (year 5). All harvested spears were trimmed to $0.23 \mathrm{~m}$. Marketable yield consisted of straight, unblemished spears $>6 \mathrm{~mm}$ in diameter.

A split-plot design with plant type as the main effect was used with data analyzed by SAS General Linear Model Procedure (SAS, 1985). Single-degree-of-freedom contrasts were used to measure irrigation treatment effects and the associated interactions. A very low plant population (12\%) was recorded for one replicate of transplant ST, apparently caused by a localized variation in soil type. Since this was identified as an outlier using the method of Snedecor and Cochran (1967), observations from this plot were subsequently omitted and Type III sum of squares was used in the analyses of variance.

\section{Results and Discussion}

Plant population of asparagus from crowns after four growing seasons averaged $94 \%(92.5 \%$ to $95.6 \%)$ of the original population, regardless of irrigation treatment (Table 1, Fig. 1). However, establishment of transplants was significantly improved with subsurface irrigation. After the fourth growing season, 83\% of the original transplant population remained with SST compared with $55 \%, 56 \%$, and $40 \%$ with NI, ST, and SPR, respectively. Plant population of transplants was significantly lower with SPR than with either ST, SST, or NI. Ferns of transplants under SPR during the first season were more likely to bend and become encased in the soil than those in other irrigation treatments. Ombrello and Garrison (1978) noted similar problems with direct-seeded seedlings.

More frequent irrigation during the first growing season may have improved plant survival of transplants. Because of the small, shallow root system of transplants early in year 1 , the
Table 1. Analysis of variance for effects of plant type and irrigation method on plant population and total yield of asparagus.

\begin{tabular}{|c|c|c|c|c|c|c|c|}
\hline \multirow{3}{*}{$\begin{array}{l}\text { Source of } \\
\text { variation }\end{array}$} & \multicolumn{4}{|c|}{ Plant survival } & \multicolumn{3}{|c|}{ Total yield } \\
\hline & \multicolumn{4}{|c|}{ Year } & \multicolumn{3}{|c|}{ Year } \\
\hline & 1 & 2 & 3 & 4 & 3 & 4 & 5 \\
\hline \multicolumn{8}{|l|}{ Main Effect } \\
\hline Plant type ${ }^{z}$ & $* *$ & $* *$ & $* *$ & $* *$ & $* *$ & $* *$ & $* *$ \\
\hline \multicolumn{8}{|l|}{ Contrasts } \\
\hline O vs. irrigation & NS & NS & NS & NS & $*$ & $* *$ & ** \\
\hline ST + SST vs. SPR & $* *$ & $* *$ & $* *$ & $* *$ & NS & $* *$ & ** \\
\hline ST vs. SST & $*$ & $* *$ & $* *$ & NS & NS & $* *$ & ** \\
\hline Plant $\times O$ vs. Irrigation & NS & NS & NS & NS & NS & NS & NS \\
\hline \multicolumn{8}{|l|}{ Plant $\times$ ST + SST vs. } \\
\hline SP & $* *$ & $* *$ & $* *$ & $* *$ & NS & $* *$ & NS \\
\hline Plant $\times$ ST vs. SST & $*$ & $* *$ & ** & $*$ & NS & $*$ & $*$ \\
\hline
\end{tabular}

zPlant type-crowns or transplants.

${ }^{\mathrm{O}} \mathrm{O}=$ no irrigation, $\mathrm{SPR}=$ sprinkler, $\mathrm{ST}=$ surface trickle, $\mathrm{SST}=$ subsurface trickle.

NS,*,**Nonsignificant or significant at $P=0.05$ or 0.01 , respectively.

soil tension measurements of the tensiometers in the row between plants may not have been an adequate measure of soil tension within the root zone. Stem diameter and plant height of crowns were significantly larger for crowns than transplants for the first three growing seasons, but not by year 4 (Table 2). In year 2, more shoots per plant were recorded for transplants than crowns, but the stems were thinner. Number of shoots per plant in years 3 and 4 , and diameter in year 4, were similar for crowns and transplants.

Vegetative growth was enhanced by irrigation, regardless of irrigation method. Irrigation increased stem diameter of both crowns and transplants in years 1 and 2, number of shoots per plant in all 4 years, and plant height in years 1,2 , and 4 . Vigorous fern development has been associated with improved root weight (Benson and Takatori, 1980; Dufault and Greig, 1983; Liptay, 1984) and improved yield during the first harvest season (Liptay, 1984).

Since the trends for total and marketable yield were quite similar, only total yield is presented in Fig. 2. Total yield in year 3 (first year of harvest) was significantly influenced by plant type and additional irrigation, but the yield in all treatments was low. Cool weather during the short (2-week) harvest season (Mapplebeck and Tiessen, 1983) may have had a greater influence on spear growth than irrigation treatment from the previous year.

Yield was significantly affected by plant type, irrigation, and method of irrigation in years 4 and 5, (Table 1, Fig. 2). The total yield $\left(\mathrm{t} \cdot \mathrm{ha}^{-1}\right)$ of each crown treatment exceeded that of transplant treatments, except SST in year 5. By year 5, the yield of transplants with SST exceeded that of crowns with NI or SPR. Benson et al. (1978) reported delayed harvest with crownestablished plantings and suggested high-density, direct-seeded plantings for some areas of California production. In our study, planting crowns resulted in greater plant survival and higher yields than transplants, except transplants with SST, during the early years of production.

Total spear production was greater for crowns than transplants, but there was no influence on average spear weight after year (Table 3). However, both the average spear weight and number of spears per hectare were enhanced by supplemental irrigation. The improved yield noted with SST is primarily a result of increased spear production (159\% of NI), since SST 


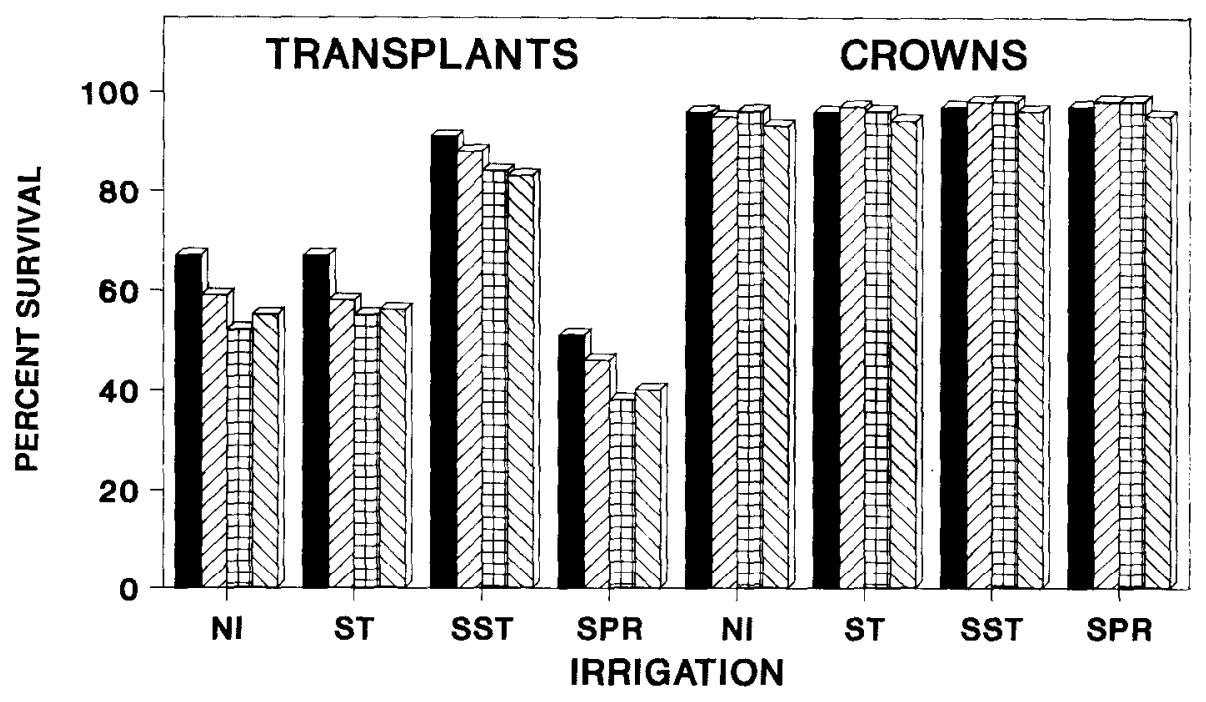

Fig. 1. Percent survival of asparagus transplants and crowns with no irrigation (NI) surface trickle (ST), subsurface trickle (SST), or sprinkler (SPR). Standard error of the mean was $6.2,6.1,6.2$, and 6.1 for 1984 through 1987 , respectively. $\mathbf{D}$, Year 1 ; 2 , year 2; year 3; year 4 .

Table 2. Stem diameter, number of shoots per plant, and plant height of asparagus from crowns and transplants as influenced by method of irrigation.

\begin{tabular}{|c|c|c|c|c|c|c|c|c|c|c|c|c|}
\hline \multirow[b]{3}{*}{ Treatment } & \multicolumn{4}{|c|}{ Stem diam $(\mathrm{mm})^{z}$} & \multicolumn{4}{|c|}{ Plant ht $(\mathrm{cm})^{y}$} & \multicolumn{4}{|c|}{ No. shoots per plant } \\
\hline & \multicolumn{4}{|c|}{ Year } & \multicolumn{4}{|c|}{ Year } & \multicolumn{4}{|c|}{ Year } \\
\hline & 1 & 2 & 3 & 4 & 1 & 2 & 3 & 4 & 1 & 2 & 3 & 4 \\
\hline \multicolumn{13}{|l|}{ Plant type } \\
\hline Crowns & 1 & 11.3 & 14.7 & 17 & 79.8 & 164 & 197 & 228 & 4.8 & 12.2 & 13.8 & 13 \\
\hline Tran & 0 & 8.5 & 12.2 & & 54.2 & 138 & 177 & 218 & 4.1 & 14.3 & 12.4 & 14 \\
\hline Signi & * & $* *$ & $* *$ & NS & $* *$ & $* *$ & $* *$ & NS & $* *$ & * & NS & NS \\
\hline \multicolumn{13}{|l|}{ Irrigation ${ }^{x}$} \\
\hline $\mathrm{NI}$ & & 8.8 & 13.1 & 16 & 58.1 & 1 & 1 & 198 & 3.8 & 7.7 & 9.9 & 7. \\
\hline S & & 10 & & & & & & 2 & 3.9 & 15.2 & 1 & 14 \\
\hline & & & & & & 1 & 1 & 1 & 5.3 & 16.3 & 1 & 14 \\
\hline SPR & 4 & 10 & & 17.7 & 71.6 & 1 & 1 & & 4.6 & 13.9 & 1 & 17 \\
\hline \multicolumn{13}{|l|}{ Contrasts } \\
\hline $\begin{array}{l}\text { NI vs. Irrigation } \\
\text { ST + SST vs. }\end{array}$ & * & ** & NS & NS & $* *$ & $* *$ & NS & $* *$ & * & ** & $* *$ & ** \\
\hline & NS & NS & NS & & NS & NS & NS & * & NS & NS & NS & 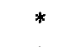 \\
\hline ST vs. SST & $*$ & NS & NS & NS & $* *$ & $*$ & NS & $* *$ & NS & NS & NS & $*$ \\
\hline \multicolumn{13}{|l|}{ Plant type $x$} \\
\hline vs. Irrigation ${ }^{w}$ & NS & NS & NS & NS & NS & NS & $* *$ & $* *$ & $*$ & NS & NS & NS \\
\hline
\end{tabular}

${ }^{2}$ Diameter of the largest stem averaged over 10 adjacent plants.

'Height of tallest fern, average of 10 adjacent plants.

$\times \mathrm{NI}=$ no irrigation, $\mathrm{SPR}=$ sprinkler, $\mathrm{ST}=$ surface trickle, $\mathrm{SST}=$ subsurface trickle.

"Other interactions: plant type $\times$ ST + SST vs. SPR and plant type $\times$ ST vs. SST not significant.

NS,*,**Nonsignificant or significant at $P=0.05$ or 0.01 , respectively.

did not increase average spear weight over other irrigation methods. Improved yield of transplants with SST can be attributed to both increased plant population (Fig. 1) and an increased number of spears per plant (data not shown).

Multiple coefficient correlation using plant population, fern height, stem diameter, and total number of stems per plant indicates a stronger relationship between yield and plant population than any of the vegetative growth measurements. (Table 4). The stalk index (number of shoots $\times$ stem diameter) of Ellison and Scheer (1959) did not improve this relationship (data not shown). This result agrees with previous observations that adequate plant establishment is essential for high yields and long-term profitability of asparagus (Benson et al., 1978: Mapplebeck and Tiessen, 1983).

The use of asparagus transplants has been advocated to avoid the cost and increased time needed to produce crowns, although transplants require more intense management of irrigation and weed control (Benson et al., 1978; Ombrello and Garrison, 1978; Sanders, 1985). While the yields reported for transplants in year 5 (except that of transplants with SST) of this study were equivalent to average commercial yields reported by Lorenz and Maynard (1988), yield was substantially improved with crowns and/or subsurface trickle irrigation.

In this study we found that improved plant survival and in- 


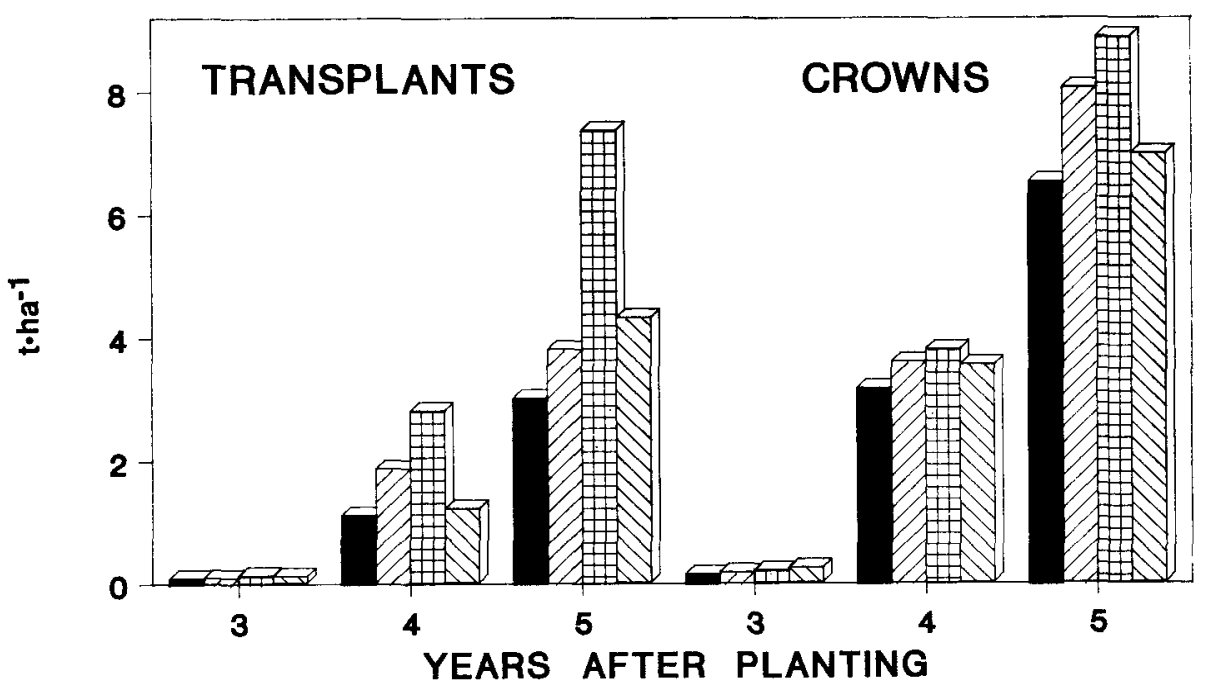

Fig. 2. Total yield $\left(t \cdot \mathrm{ha}^{-1}\right)$ of transplants and crowns in years 3 (first harvest season), 4, and 5 as influenced by planting method and irrigation method. Standard error of the mean was $0.02,0.19$, and 0.48 for 1986 through

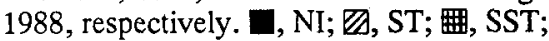
$\triangle$, SPR.
Table 3. Average spear weight and spear number as influenced by plant type and irrigation method.

\begin{tabular}{|c|c|c|c|c|c|c|}
\hline \multirow[b]{3}{*}{ Treatment } & \multirow{2}{*}{\multicolumn{3}{|c|}{$\begin{array}{c}\begin{array}{c}\text { Average spear wt } \\
\text { (g/spear) }\end{array} \\
\text { Year }\end{array}$}} & \multirow{2}{*}{\multicolumn{3}{|c|}{$\begin{array}{c}\begin{array}{c}\text { Spear number } \\
(1000 / \mathrm{ha})\end{array} \\
\text { Year } \\
\end{array}$}} \\
\hline & & & & & & \\
\hline & 3 & 4 & 5 & 3 & 4 & 5 \\
\hline \multicolumn{7}{|l|}{ Plant type } \\
\hline Crowns & 17.7 & 22.3 & 23.9 & 24.1 & 159 & $31^{\prime}$ \\
\hline Transplants & 12.2 & 22.4 & 25.0 & 18.5 & 79 & 186 \\
\hline Significance & $* *$ & NS & NS & $* *$ & $* *$ & $* *$ \\
\hline \multicolumn{7}{|l|}{ Irrigation } \\
\hline NI & 17.5 & 19.9 & 22.8 & 18.1 & 106 & 20 \\
\hline ST & 13.5 & 23.4 & 25.2 & 19.4 & 126 & 23 \\
\hline SST & 13.9 & 22.1 & 24.6 & 22.8 & 150 & 33 \\
\hline SPR & 15.1 & 24.0 & 25.2 & 25.0 & 100 & \\
\hline \multicolumn{7}{|l|}{ Contrasts ${ }^{z}$} \\
\hline NI vs. Irrigation & $* *$ & $* *$ & $* *$ & $* *$ & $*$ & $*$ \\
\hline ST + SST vs. SPR & NS & NS & NS & NS & $* *$ & \\
\hline ST vs. SST & NS & NS & NS & NS & $* *$ & \\
\hline Plant $\times$ NI vs. Irrigation ${ }^{y}$ & NS & NS & $*$ & NS & NS & NS \\
\hline Plant $\times$ ST vs. SST & NS & NS & NS & NS & NS & \\
\hline
\end{tabular}

${ }^{2} \mathrm{NI}=$ no irrigation, $\mathrm{SPR}=$ sprinkler, $\mathrm{ST}=$ surface trickle, $\mathrm{SST}=$ subsurface trickle.

y Interaction Plant $\times$ ST + SST vs. SPR nonsignificant.

NS,*,**Nonsignificant or significant at $P=0.05$ or 0.01 , respectively.

Table 4. Multiple correlation coefficients using growth variables to estimate yield.

\begin{tabular}{lllll}
\hline Model & $\begin{array}{c}\text { Variables } \\
\left.\text { (partial } R^{2}\right)\end{array}$ & 1986 & 1987 & 1988 \\
\hline Total yield & Model $\left(R^{2}\right)$ & $0.24^{*}$ & $0.98^{* *}$ & $0.81^{*}$ \\
& $\begin{array}{l}\text { Plant population } \\
\text { Stem diameter }\end{array}$ & $0.24^{* *}$ & $0.84^{* *}$ & $0.66^{* *}$ \\
& $\begin{array}{l}\text { Sumber of } \\
\text { Numb }\end{array}$ & $0.07^{* *}$ & $0.12^{* *}$ \\
& shoots & $\ldots$ & $0.03^{* *}$ & $0.03^{* *}$ \\
\hline
\end{tabular}

${ }^{2}$ Variable not in the model of the year indicated.

****Significant at $P=0.05$ or 0.01 , respectively.

creased yield during the early harvest seasons can be obtained with crowns rather than transplants, when adequate supplemental irrigation is not available. However, Sterrett et al. (1978) reported lower cost of establishment for transplants with SST than for crowns without irrigation, provided the facilities for trickle irrigation (water source, pump, etc.) are available. When SST is feasible, the slightly higher yield from crowns may be offset by the expediency (time, cost of plants, and labor) of planting transplants. Since asparagus is a perennial crop that requires a long-term investment, improved plant survival of crowns or transplants with SST, and improved yield with trickle irrigation, would benefit growers by increased economic return during the early harvest seasons.

\section{Literature Cited}

Benson, B. L., G.C. Hanna, and F.H. Takatori. 1978. Evaluation of crown planting and direct seeding of asparagus after 15 years. Calif. Agr. 32(3):13-14.

Benson, B.L. and F.H. Takatori. 1980. Partitioning of dry matter in open-pollinated and $\mathrm{F}_{1}$ hybrid cultivars of asparagus. J. Amer. Soc. Hort. Sci. 105:567-570.

Bucks, D. A., F.S. Nakayama, and A. W. Warrick. 1982. Principles, practices, and potentialities of trickle (drip) irrigation, p. 220-298 In: D. Hillel (cd.). Advances in irrigation. vol. 1. Academic, New York.

Chase, R.G. 1985. Subsurface trickle irrigation in a continuous cropping system. Drip/trickle irrigation in action. Amer. Soc. Agr. Eng. II:909-914.

Damicone, J.P. and W.J. Manning. 1987. Influence of management practices on severity of stem and crown rot, incidence of asparagus minor, and yield of asparagus grown from transplants. Plant Dis. 71:81-84.

Dufault, R.J. and J.K. Greig. 1983. Dynamic growth characteristics in seedling asparagus. J. Amer. Soc. Hort. Sci. 108:1026-1030.

Elfving, D.C. 1979. Performance of young apple trees under trickle irrigation. Proc. N.Y. State Hort. Soc. 124:73-76.

Elfving, D.C. 1982. Crop response to trickle irrigation. Hort. Rev. $4: 1-48$.

Ellison, J.H. and D.F. Scheer. 1959. Yield related to brush vigor in asparagus. Proc. Amer. Soc. Hort. Sci. 73:339-344.

Fisher, K.J. 1982. Comparison of the growth and development of young asparagus plants established from seedling transplants and by direct seedling. New Zealand J. Expt. Agr. 10:405-408.

Kirpes, D. J., R.J. Folwell, J.A. Gefre, J.W. Schorr, and G. Tamaki. 1985. Asparagus production practices and the asparagus aphid infestation problem. Wash. State Univ. Res. Bul. 0951.

Liptay, A. 1984. Effect of time and transplanting of field-seeded asparagus on establishment and yield of the crop. Commun. J. Plant Sci. 64:219-221. 
Lorenz, O.A. and D.N. Maynard. 1988. Knotts' handbook for vegetable growers. 3rd ed. Wiley, New York.

Mapplebeck, L.R. and H. Tiessen. 1983. Asparagus production in Canada. Univ. of Guelph, Guelph, Ont., Canada.

Mitchell, W.H. and D.L. Sparks. 1982. Influence of subsurface irrigation and organic additions on top and root growth of field corn. Agron. J. 74:1084-1088.

Moon, D.M. 1976. Yield potential of Asparagus officinalis L., New Zealand J. Agr. Res. 19:435-438.

NOAA. 1984. Virginia Climatol. Data. Annu. Summ. 94(13):6-8.

Ombrello, T.M. and S.A. Garrison. 1978. Establishing asparagus from seedling transplants. HortScience 13:663--664.

Phene, C. J., K.R. Davis, R.B. Hutmacher, and R.L. McCormick. 1987. Advantages of subsurface irrigation for processing tomatoes. Acts Hort. 200:101-114.

Pogue, W.R. and S.G. Dooley. 1985. Tensiometer management of soil water. Drip/trickle irrigation in action. Amer. Soc. Agr. Eng. II:761-766.
Price, H. C., J.J. Grajanskis, J. Ramey, D. Ramey, and R. Ramey. 1986. Asparagus cultivar trial, p. 8-13. In: H.C. Price. B.H. Zandstra, E.J. Hanson, R.A. Baughan, N.D. Blakely, J.J. Grajauskis, and T.F. Wallner, Jr. (eds.). 1986 Vegetable crops research. Michigan State Univ. Hort. Rpt. 41.

Sammis, T.W. 1980. Comparison of sprinkler, trickle, subsurface, and furrow irrigation methods for row crops. Agron. J. 72:701-704.

Sanders, D.C. 1985. Direct seeding and transplanting commercial asparagus. North Carolina Agr. Expt. Sta. Lflt. 2-E.

SAS Institute, Inc. 1985. SAS user guide statistics. SAS Institute, Cary, N.C.

Snedecor, G.W. and W.G. Cochran. 1967. Statistical methods. 6th ed. Iowa State Univ. Press Ames.

Sterrett, S.B., B.B. Ross, and C.P. Savage, Jr. 1987. Stand establishment of asparagus transplants and crowns as influenced by irrigation method. Proc. Natl. Agr. Plastics Congr. 20:247-252.

Wilcox-Lee, D. 1987. Soil matric potential, plant water relations, and growth in asparagus. HortScience 22:22-24. 